\title{
Solitary fibrous tumor of the male breast: a case report and review of the literature
}

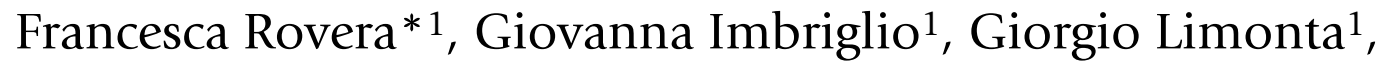 \\ Marina Marelli1 ${ }^{1}$, Stefano La Rosa ${ }^{2}$, Fausto Sessa ${ }^{3}$, Gianlorenzo Dionigi1, \\ Luigi Boni ${ }^{1}$ and Renzo Dionigi ${ }^{1}$
}

\begin{abstract}
Address: ${ }^{1}$ Department of Surgical Sciences, Ospedale di Circolo, Varese, Italy, ${ }^{2}$ Department of Pathology, Ospedale di Circolo, Varese, Italy and ${ }^{3}$ Department of Human Morphology, University of Insubria Varese and Department of Pathology, Multimedica, Milano, Italy

Email: Francesca Rovera* - francesca.rovera@uninsubria.it; Giovanna Imbriglio - rancesca.rovera@uninsubria.it;

Giorgio Limonta - rancesca.rovera@uninsubria.it; Marina Marelli - rancesca.rovera@uninsubria.it; Stefano La Rosa - anapat@ospedale.varese.it; Fausto Sessa - anapat@ospedale.varese.it; Gianlorenzo Dionigi - gianlorenzo.dionigi@uninsubria.it; Luigi Boni - luigi.boni@uninsubria.it;

Renzo Dionigi - renzo.dionigi@uninsubria.it

* Corresponding author
\end{abstract}

Published: 7 February 2008

World Journal of Surgical Oncology 2008, 6:16 doi:10.1186/1477-7819-6-16

This article is available from: http://www.wjso.com/content/6/1/16

(C) 2008 Rovera et al; licensee BioMed Central Ltd.

This is an Open Access article distributed under the terms of the Creative Commons Attribution License (http://creativecommons.org/licenses/by/2.0), which permits unrestricted use, distribution, and reproduction in any medium, provided the original work is properly cited.
Received: 6 November 2007

Accepted: 7 February 2008

\begin{abstract}
Extrapleural solitary fibrous tumors are very rare and occasionally they appear in extraserosal soft tissues or parenchymatous organs. In such cases the right preoperative diagnosis is often difficult and challenging, because both radiological and cytological examinations are not exhaustive. For these reasons, surgical excision is frequently the only way to reach the correct diagnosis and to achieve definitive treatment. A few cases of solitary fibrous tumors have been also described in the breast. Although rare, this lesion opens difficulties in preoperative diagnosis entering in differential diagnosis with other benign lesions as well as with breast cancer. In this article we describe a case of a solitary fibrous tumor of the breast in a 49-year-old man. Problems related to differential diagnosis and the possible pitfalls that can be encountered in the diagnostic iter of such rare tumor are discussed.
\end{abstract}

\section{Case presentation}

A 49-year-old white man presented at Department of Surgical Sciences of the University of Insubria in January 2007 due to a palpable painless nodule of the right breast, that he occasionally detected 3 months before. The patient had a positive family history for breast cancer (his mother was affected at the age of 55 years). His personal and pathological anamnesis did not highlight any significant evidence. Physical examination showed a lump of about $3 \mathrm{~cm}$ in the retroareolar region of the right breast, with well-defined margins, tense elastic consistence on palpation, mobile without skin or nipple-areola complex alterations. No ipsilateral axillary nodes have been detected. Breast ultrasound and fine-needle aspiration were performed. Breast ultrasound showed in the right retroareolar region, a solid mass of $3 \times 1 \mathrm{~cm}$ with homogeneous echostructure and well-defined margins (fig. 1). These clinical and radiological data were highly suggestive for fibroadenoma. In cytological specimens only benign duct cells were observed. A surgical treatment was planned, with both diagnostic and therapeutic goals. The patient underwent surgical resection of the lesion in March 2007. Macroscopically, tumor presented as a white-grayish well demarcated unencapsulated nodule of 


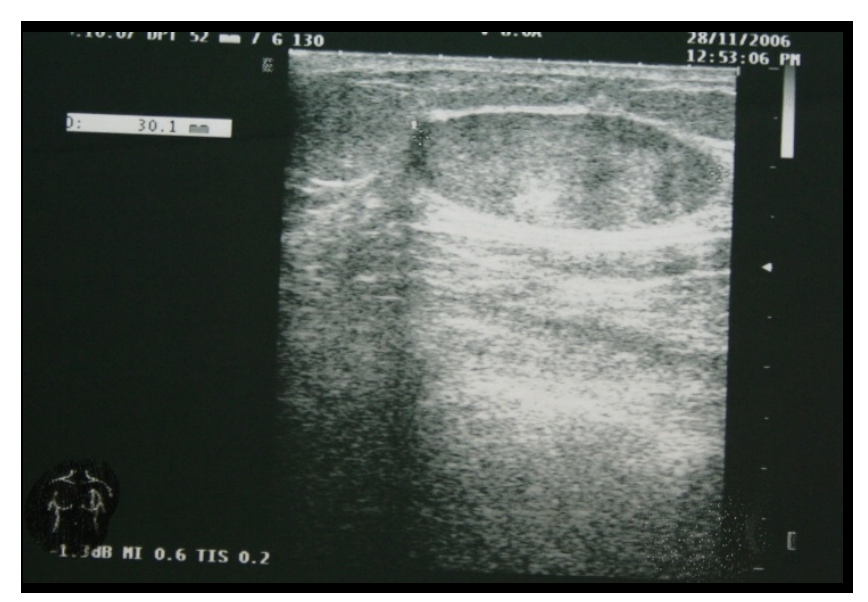

Figure I

Breast ultrasound showed in the right retroareolar region, a solid mass of $3 \times 1 \mathrm{~cm}$ with homogeneous echostructure and well-defined margins.

$28 \mathrm{~mm}$ in diameter. Histologically, the lesion was composed of a proliferation of bland-looking cells admixed with thin collagen fibers. Cell appearance ranged from fibroblastic-like cells with elongated nuclei and scanty cytoplasm, to epitheliod-like oval cells with abundant eosinophilic cytoplasm and round to oval, centrally located, nuclei. No mitoses were found as well as areas of necrosis or hemorrhage. Immunohistochemical stains, performed using the avidin-biotin complex procedures, showed immunoreactivity for vimentin and CD34, while cells were completely negative for S100-protein, $\alpha$ - smooth muscle actin, desmin, cytoheratin AE1/AE3, and neurofilaments (fig. 2 A,B,C). On the basis of these morphological and immunohistochemical findings the diagnosis of solitary fibrous tumor was made.

\section{Discussion}

Fibrous tumors involving the mammary gland are uncommon and account for less than $0.2 \%$ of all primary breast lesions, without a striking difference of incidence between male and female as for ductal epithelial cancers [1]. The majority of cases described in the literature occurred in the thoracic cavity, but various sites, including head and neck $[2]$, liver [3], skin [4], soft tissue $[5,6]$ and meninges $[7,8]$, were recognized. Extraserosal solitary fibrous tumor can be included in the group of benign spindle stromal tumors of the breast, which encompasses a spectrum of lesions sharing several basic common clinical, morphological, and immunohistochemical analogies [9]. Tumors with similar features have been reported in the literature with different names, frequently used interchangeably, creating confusion of terminology among pathologists and clinicians. The unifying morphological criterion of all these lesions is represented by a well-circumscribed proliferation of bland-looking spindly to oval-epithelioid cells forming short fascicles and/or clusters, admixed with thick or thin collagen bands. Recently, Magro et al. proposed to subdivide these tumors in two main groups: the fibroblastic and myofibroblastic types (2002). Although both categories have a basic common immunophenotype characterized by immunoreactivity for vimentin, CD34, $\mathrm{Bcl} 2$ and $\mathrm{CD} 99$, they differentiate for the expression of myogenic markers including $\alpha$-smooth muscle actin and
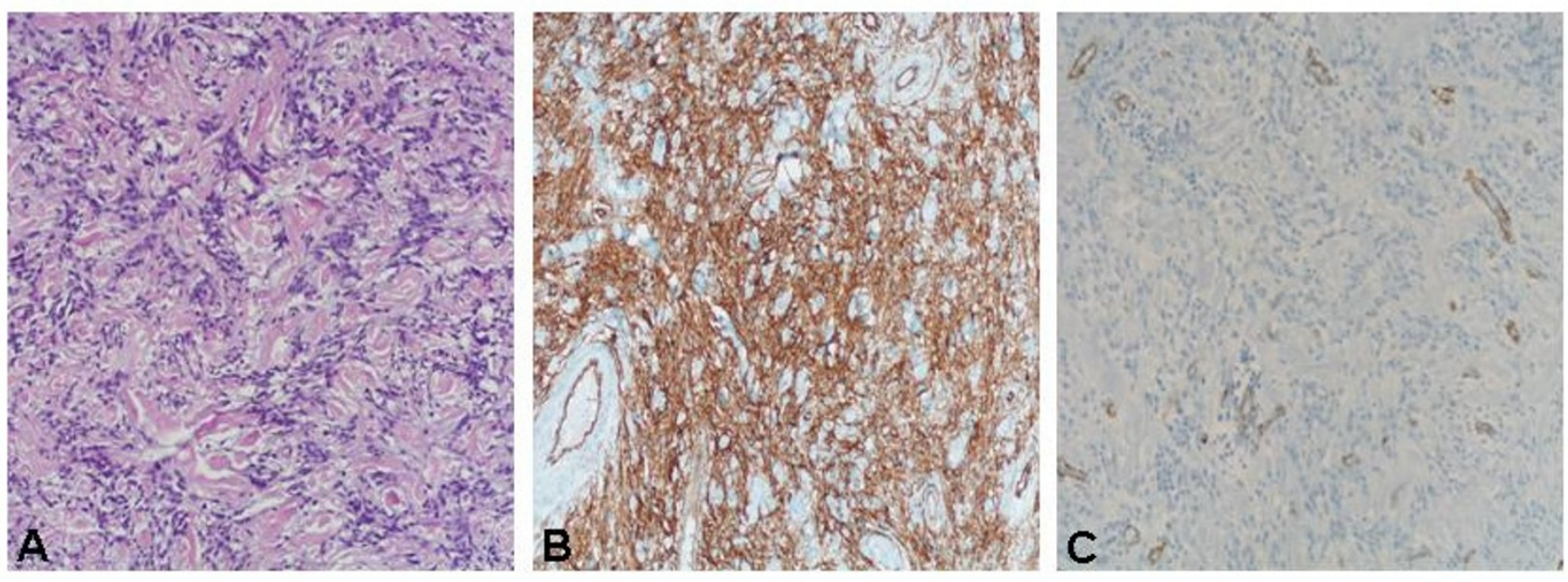

\section{Figure 2}

A,B,C: The tumor consists of a proliferation of bland-looking cells admixed with thin collagen fibers. Cell appearance ranged from fibroblastic-like cells with elongated nuclei and scanty cytoplasm (A). Cells were immunoreactive for CD34 (B), while they were completely negative for smooth muscle actin (C). 
Table I: Main morphological features of mesenchymal lesions of the breast

\begin{tabular}{|c|c|c|c|c|c|c|c|c|c|c|c|c|c|c|}
\hline Tumor type & atypia & $\begin{array}{l}\text { vascular } \\
\text { component }\end{array}$ & hemorrhage & necrosis & mitoses & CK & EMA & Vim & CD34 & $\mathrm{Bcl} 2$ & CD99 & actin & desmin & S100 \\
\hline Solitary fibrous tumor & no & prominent & no & no & rare & $-/+$ & $+/-$ & + & + & + & + & $-/+$ & $-/+$ & $-/+$ \\
\hline Myofibroblastoma & no & present & no & no & rare & - & - & + & $+/-$ & $+/-$ & $+/-$ & + & + & - \\
\hline Fibromatosis & no & scarce & no & no & rare & - & & + & & & & $-/+$ & - & - \\
\hline Hemangiopericytoma & mild & abundant & no & rare & variable & & & + & $+/-$ & & $+/-$ & $-/+$ & $-/+$ & \\
\hline Nodular fascitis & no & abundant & $\begin{array}{c}\text { red cell } \\
\text { extravasion }\end{array}$ & no & present & - & & & & & & + & $+/-$ & - \\
\hline $\begin{array}{l}\text { Inflammatory myofibroblastic } \\
\text { tumor* }\end{array}$ & mild & abundant & no & no & & $-/+$ & & + & & & & $+/-$ & + & - \\
\hline Leiomyoma & no & normal & no & no & rare & - & - & + & - & - & - & + & + & - \\
\hline Metaplastic carcinoma & yes & normal & no & rare & present & + & $-/+$ & + & - & & & + & & - \\
\hline Myoepithelioma & mild & normal & no & no & present & + & & & - & & & + & - & + \\
\hline $\begin{array}{l}\text { Pseudoangiomatous stromal } \\
\text { hyperplasia }\end{array}$ & no & $\begin{array}{l}\text { pseudovascular } \\
\text { spaces }\end{array}$ & no & no & no & - & - & + & + & - & - & + & - & - \\
\hline
\end{tabular}

CK: cytokeratin; EMA: epithelial membrane antigen; Vim: vimentin; *: ALK positive

desmin, lacking in the former and strongly expressed in the latter one $[9,10]$. Main morphological features of mesenchymal lesions of the breast are described in table 1.

The interest of the present case relies on its rarity and in the difficulties to achieve the exact diagnosis, because this tumor has no typical radiological features and cytological aspects cannot frequently solve the diagnostic doubts between benign and malignant lesion. Tumors appear as single nodules, generally with well defined borders and enter in differential diagnosis with other more common lesions, including fibroadenomas and fillodes tumors. Moreover, breast cancer cannot be ruled out on the basis of radiological features. Cytology can help in the differential diagnosis from breast cancer, but could not in differentiating from other mixed epithelial-mesenchymal tumors. For all these reasons, the exact diagnosis is frequently achieved after surgical resection, that also has a curative purpose. Histologically, differential diagnosis of solitary fibrous tumors includes a wide variety of other benign and malignant bland-looking monomorphic spindle cell lesions of the breast, including nodular fascitis, inflammatory myofibroblastic tumor, fibromatosis, benign peripheral nerve sheet tumors, haemangiopericytomas and leiomyomas [10-12]. The differential diagnosis includes breast myofibroblastoma that shows the same morphological features, but differentiates for the expression of muscle-related antigens such as actin and desmin $[9,10]$. For this reason immunohistochemistry is a main tool in order to reach a correct diagnosis. However, the two entities have substantially the same clinical and biological behavior. Furthermore, differential diagnosis of a breast mass in a male routinely must distinguish from gynecomastia, which remains the most common cause of either unilateral or bilateral breast mass, frequently associated to hormonal therapy. Although more commonly bilateral and symmetric with well-defined discoid margins, histopatologic confirmation is the only sure differential between benign and malignant disease.
The differential diagnosis from cancer is the most important issue due to the very different prognostic implication. Although in surgical specimen this differential diagnosis is generally easy, on small bioptic or cytological specimens it may be difficult. In particular the detection in such preparations of epithelioid cells arranged in Indian files may mimic an infiltrating lobular carcinoma. Immunohistochemistry showing negativity for epithelial markers helps in excluding the presence of a breast cancer.

The treatment of choice for solitary fibrous tumours is extensive surgical resection. Up to now there is no evidence that chemotherapy and radiation are effective. The local recurrence or onset of metastases mainly depends on histological parameters. Although most solitary fibrous tumours are characterized by a non-aggressive clinical course, some can recur locally or display malignant behaviour, so a strict and long-term follow-up is recommended mainly for atypical forms.

\section{Acknowledgements}

The consent for publication from the patient was obtained.

\section{References}

I. Bombonati A, Parra JS, Schwartz GF, Palazzo JP: Solitary fibrous tumor of the breast. Breast J 2003, 9:25I.

2. Hofmann $T$, Braun $H$, Kole W, Beham A: Solitary fibrous tumor of the submandibular gland. Eur Arch Otorhinolaryngol 2002, 259:470-473.

3. Bost F, Barnoud R, Peoc'h M, Le Marc'hadour F, Pasquier D, Pasquier $B:$ CD34 positivity in solitary fibrous tumor of the liver. Am J Surg Pathol 1995, 19:1334-1335.

4. Cowper S, Kilpatrick T, Proper S, Morgan MB: Solitary fibrous tumor of the skin. Am J Dermatopathol 1999, 21:213-219.

5. Krismann M, Adams H, Jaworska M, Muller KM, Johnen G: Benign solitary fibrous tumour of the thigh: morphological, chromosomal and differential diagnostic aspects. Langenbecks Arch Surg 2000, 385:52I-525.

6. Suster S, Nascimento AG, Miettinen M, Sickel JZ, Moran CA: Solitary fibrous tumors of soft tissue. A clinicopathologic and immunohistochemical study of 12 cases. Am J Surg Pathol I 995, 19:1257-1266.

7. Carneiro SS, Scheithauer BW, Nascimento AG, Hirose T, Davis DH: Solitary fibrous tumor of the meninges: a lesion distinct from fibrous meningioma. Am J Clin Pathol 1996, 106:2 17-224. 
8. Chilosi M, Facchetti F, Dei Tos AP, Lestani M, Morassi ML, Martignoni G, Sorio C, benedetti A, Morelli L, Doglioni C, Barberis M, Menestrina $\mathrm{F}$, Viale G: Bcl-2 expression in pleural and extrapleural solitary fibrous tumours. J Pathol 1997, I 8 I:362-367.

9. Magro G, Bisceglia M, Michal M, Eusebi V: Spindle cell lipoma-like tumor, solitary fibrous tumor and myofibroblastoma of the breast: a clinico-pathological analysis of 13 cases in favour of a unifying histogenetic concept. Virchows Arch 2002, 440:249-260.

10. Magro G, Sidoni A, Bisceglia M: Solitary fibrous tumor of the breast: distinction from myofibroblastoma. Histopathology 2000, 37:|89-19|.

II. Al Nafussi A: Spindle cell tumours of the breast: practical approach to diagnosis. Histopathology 1999, 35:1-13.

12. McMenamin ME, DeSchryver K, Fletcher CDM: Fibrous lesions of the breast. A review. Int J Surg Pathol 2000, 8:99-108.

Publish with Bio Med Central and every scientist can read your work free of charge

"BioMed Central will be the most significant development for disseminating the results of biomedical research in our lifetime. "

Sir Paul Nurse, Cancer Research UK

Your research papers will be:

- available free of charge to the entire biomedical community

- peer reviewed and published immediately upon acceptance

- cited in PubMed and archived on PubMed Central

- yours - you keep the copyright

Submit your manuscript here:

http://www.biomedcentral.com/info/publishing_adv.asp 